\title{
Synthesis and Identification of 2-Pentadecyl-Quinazolinylthiourea (PQT) As Corrosion Inhibitor for Carbon Steel in Acidic Solution
}

\author{
Haider M.M. Al-tamimy* andSuaad M.H. Al-Majidi \\ Department of Chemistry, College of Science / University of Baghdad, Iraq
}

\begin{abstract}
A new fatty chain derivative of quinazolinone has been synthesized from the two simple precursors of 2-amino benzoic acid and palmitoyl chloride. The novel quinazolinone derivative is obtained via the nucleophilic interaction of 2-palmitoyl-4H-1, 3-benzoxazine -4-one with thiosemicarbazide that yield 2pentadecyl-quinazolinylthiourea $(P Q T)$. Newly synthesized compound was identified via spectral methods; their [FTIR, ${ }^{1} \mathrm{H}$-NMR and ${ }^{13} \mathrm{C}$-NMR] and measurement of some of its physical properties. Furthermore the inhibition effect of synthesized compound on the corrosion of carbon steel in $2 \mathrm{~N} \mathrm{HCl}$ was studied by potentiodynamic polarization. Morphology of the carbon steel was examined using scanning electron microscopy (SEM) in presence and absence of inhibitor.
\end{abstract}

Keywords: Quinazolinone derivatives, Acid corrosion, Carbon steel,Corrosion inhibitor.

\section{Introduction}

Corrosion is a fundamental process playing an important role in economics and safety, especially for metals. The use of inhibitors is one of the most practical methods for protection against corrosion, particularly in acidic media [1].Most well-known acid inhibitors are organic compounds which have $\pi$ bonds and contains hetero atoms such as nitrogen, sulphur, oxygen and phosphorous which allows the adsorption of compounds on the metal surface[2], thus resulting adsorption film acts as a barrier separating the metal from the corrosive medium and blocks the active sites [3].

Carbon steel is the most important metal used in industry as construction metal for metallurgical industries and is used as construction material for pipes in oil and gas industry and transmission pipelines $[4,5]$.

Acid solutions are widely used in industry. Some of the important fields of application being acid pickling of iron and steel, chemical cleaning and processing, ore production and oil well acidification. In acidic media, the use of hydrochloric acid in pickling of metals, acidization of oil wells and in cleaning of scales is more economical, efficient and trouble-free compared to other mineral acids [6].

Quinazolinone derivatives represent one of the most classes of heterocyclic compounds possessing a wide spectrum of biological activity [7]. These derivatives are the subject of many research studies due to their widespread potential biological activities such as antimicrobial [8], anti-inflammatory [9],antitumor[10]and anticancer[11].

The main objective of this investigation is to synthesis and study the inhibitive effect of 2-pentadecylquinazolinylthiourea $(\mathrm{PQT})$ ) for the carbon steel surface in hydrochloric acid solution using potntiostate polarization method.

\subsection{Synthesis of 1, 3-benzoxazin-4-one derivative:}

\section{Experimental}

To a stirred solution of anthranilic acid $(1.37 \mathrm{gm}, 0.01 \mathrm{~mole})$ in dry acetone, palmitoyl chloride $(3 \mathrm{ml}$, $0.01 \mathrm{~mole}$ ) was added in presence of pyridine as solvent. The mixture was refluxed for $3 \mathrm{hrs}$ then concentrated under vacuum. The solid product that separated on cold was filtrated off, dried and crystallized from petroleumether. The product was heated for $4 \mathrm{hrs}$ under reflux in acetic anhydride then concentrated under vacuum. The pale yellow solid which separated was filtered, washed with water and recrystallized to give yield $70 \%$. M.P $48-50^{\circ} \mathrm{C} .[12]$

\subsubsection{Synthesis of 2-pentadecyl-quinazoliny-3-lthiourea (PQT) as corrosion inhibitor:}

To a solution of compound (1) $(3.57 \mathrm{gm}, 0.01 \mathrm{~mole})$ in $30 \mathrm{ml}$ pyridine, thiosemicarbazide $(0.908 \mathrm{gm}$, 0.01 mole) was added and the reaction mixture was heated under reflux for $8 \mathrm{hrs}$, and poured into cold diluted $\mathrm{HCl}$. the crud solid product that separated was filtered off, washed with water, dried and recrystallized from ethanol to give compound (2) yield $80 \%$ M.P $98-100^{\circ}$ C.[13]

The compounds (1 and 2) were synthesized as shown in scheme (1). 


\section{2 preparation of Specimen:}

A carbon steel sheet was used as working electrode for polarization method with Area $\left(1 \mathrm{~cm}^{2}\right)$ its composition is: $(0.086 \% \mathrm{C}, 0.252 \% \mathrm{Mn}, 0.003 \% \mathrm{P}, 0.016 \% \mathrm{~S}$ and the remainder being Fe was used.). $2 \mathrm{~N}$ Hydrochloric acid solutions were prepared using distilled water.

\subsection{Polarization Techneque:}

By using a Wenking M Lab potentiostat and a three electrode cell, electrochemical studies were performed. Platinum over Titanium (Pt/Ti) electrode was used as the auxiliary electrode and a saturated silver electrode $\mathrm{Ag} / \mathrm{AgCl}$ as the reference electrode. The corrosion rates are determined by Tafel extrapolation technique. The experiments were conducted at 298k, 308k, 318k and 328k.

\subsection{Synthesis of 2-pentadecyl-quinazolinylthiourea (PQT):}

The new 2-pentadecyl-quinazolinylthiourea (PQT) was synthesized following the reaction sequences depicted in scheme (1). Anthranilic acid reacted with Palmitoyl chloride in dry acetone to produce anthranilamide derivative which was cyclized with acetic anhydride to give 4H,1,3-benzoxazinone (1). Quiazolinylthiourea (2) was obtained when compound (1) was reacted with thiosemicarbazide.The structure of compound(1) was confirmed by FT-IR spectrum which showed $v(\mathrm{C}-\mathrm{H})$ aromatic at $3030 \mathrm{CM}^{-1}, v(\mathrm{C}-\mathrm{H})$ aliphatic (2923 , 2854) $\mathrm{CM}^{-1}, v(\mathrm{C}=\mathrm{O})$ of benzoxazinone(lacton) $1761 \mathrm{CM}^{-1}, v(\mathrm{C}=\mathrm{N}) 1637 \mathrm{CM}^{-1}[14]$ and by ${ }^{1} \mathrm{H}-\mathrm{NMR}$ $\left(\mathrm{DMSO}-\mathrm{d}^{6}\right)$ which showed $\delta 0.8\left(\mathrm{t}, 3 \mathrm{H}\right.$, terminal $\left.\mathrm{CH}_{3}\right), \delta 1.1-1.3\left(\mathrm{~m}, 30 \mathrm{H}, 15 \mathrm{CH}_{2}\right.$ of alkyl chain), $\delta 7.0-7.9(\mathrm{~m}$, $4 \mathrm{H}, \mathrm{ArH})[15]$ fig (1). Compound (2) FT-IR spectral data showed absorption $v(\mathrm{C}-\mathrm{H})$ aromatic at $3062 \mathrm{CM}^{-1}, v\left(\mathrm{C}^{-}\right.$ $\mathrm{H})$ aliphatic at $(2918,2850) \mathrm{CM}^{-1}, v(\mathrm{C}=\mathrm{O})$ amide at $1690 \mathrm{CM}^{-1}, \mathrm{NH}_{2}$ at $\left(3358 \mathrm{CM}^{-1}\right.$ asym, $\left.3260 \mathrm{CM}^{-1} \mathrm{sym}\right) \mathrm{vNH}$ at $3155 \mathrm{CM}^{-1}{ }^{1} \mathrm{H}-\mathrm{NMR}$ spectrum showed $\delta 0.9\left(\mathrm{t}, 3 \mathrm{H}\right.$, terminal $\left.\mathrm{CH}_{3}\right), \delta 1.2-1.5\left(\mathrm{~m}, 30 \mathrm{H}, 15 \mathrm{CH}_{2}\right.$ of alkyl chain), $\delta 6.8-7.5(\mathrm{~m}, 4 \mathrm{H}, \mathrm{ArH}), \delta 8.0,8.5$ and $11.1\left(\mathrm{~s}, 3 \mathrm{H}, \mathrm{NH}\right.$ exchangeable) fig $(2) .{ }^{13} \mathrm{C}-\mathrm{NMR}$ spectrum of compound (1) showed signals at $\delta=(134) \mathrm{ppm}, \delta=(127) \mathrm{ppm}, \delta=(147.00) \mathrm{ppm}, \delta=(122) \mathrm{ppm}, \delta=(160.53)$ $\mathrm{ppm}, \delta=(148) \mathrm{ppm}$, and at $\delta=(22-27) \mathrm{ppm}$ belong to $(-\mathrm{CH}-\mathrm{CH})$ of $\mathrm{C} 1,(-\mathrm{CH}-\mathrm{CH})$ of $\mathrm{C} 2,(-\mathrm{C}-\mathrm{N})$ of $\mathrm{C} 3,(-\mathrm{C}-$ $\mathrm{C}=\mathrm{O})$ of $\mathrm{C} 3,(\mathrm{C}=\mathrm{O})$ ester of $\mathrm{C} 5,(\mathrm{C}=\mathrm{N})$ imine of $\mathrm{C} 6$ and long chain $\left.\mathrm{C}_{15} \mathrm{H}_{31}\right)$ fig(3). ${ }^{13} \mathrm{C}-\mathrm{NMR}$ of compound (2) showed absorption at $\delta=(174.5)$ ppm belong to $(\mathrm{C}=\mathrm{S})$ and another absorption fig (4).Spectral data of compound (1and 2) were showed in Table (1).

Scheme (1): Synthetic route of inhibitor (PQT) 
Synthesis And Identification Of 2-Pentadecyl-Quinazolinylthiourea (PQT) As Corrosion Inhibitor...

Table (1)physical properties andSpectral data of compound (1and 2)

\begin{tabular}{|c|c|c|c|c|c|c|c|}
\hline $\begin{array}{l}\text { Com. } \\
\text { No. }\end{array}$ & Structures & M.P (C) & $\begin{array}{c}\text { Yiele } \\
\text { d } \\
\%\end{array}$ & color & $\begin{array}{l}\text { Major FT-IR } \\
\text { absorption } \\
\left(\mathrm{CM}^{-1}\right)\end{array}$ & ${ }^{1}$ H-NMR ( $\square$ ppm) & $\begin{array}{c}{ }^{13} \text { C-NMR ( } \\
\text { ppm) }\end{array}$ \\
\hline 1 & & $48-50$ & 70 & $\begin{array}{l}\text { Pale } \\
\text { yellow }\end{array}$ & $\begin{array}{c}3030 v(\mathrm{C}-\mathrm{H}) \\
\text { arom, } \\
2923-2854 \\
v(\mathrm{C}-\mathrm{H}) \text { aliph, } \\
1761 v(\mathrm{C}=\mathrm{O}) \\
1637 v(\mathrm{C}=\mathrm{N})\end{array}$ & $\begin{array}{c}\delta 0.8\left(\mathrm{t}, 3 \mathrm{H}, \mathrm{CH}_{3}\right), \\
\delta 1.1-1.3(\mathrm{~m}, 30 \mathrm{H}, \\
\left.15 \mathrm{CH}_{2}\right), \\
\delta 7.0-7.9(\mathrm{~m}, \\
4 \mathrm{H}, \mathrm{ArH})\end{array}$ & $\begin{array}{c}\text { 134(C1), 127(C2), } \\
147(\mathrm{C} 3), 122(\mathrm{C} 4), \\
160.5(\mathrm{C} 5), \\
148(\mathrm{C} 6), \\
22-27 \text { (Long chain } \\
\text { C7) }\end{array}$ \\
\hline 2 & & $98-100$ & 80 & $\begin{array}{c}\text { Off } \\
\text { white }\end{array}$ & $\begin{array}{c}(3358,3260) \\
v \mathrm{NH} 2, \\
3155 v \mathrm{NH} \\
3062 v(\mathrm{C}-\mathrm{H}) \\
\text { arom, } \\
2918-2850 v(\mathrm{C}- \\
\text { H) aliph, } \\
1690 v(\mathrm{C}=\mathrm{O}) \\
\text { amide } \\
1608 v(\mathrm{C}=\mathrm{N}),\end{array}$ & $\begin{array}{c}\delta 0.9(\mathrm{t}, 3 \mathrm{H}, \\
\left.\text { terminal } \mathrm{CH}_{3}\right), \\
\delta 1.2-1.5(\mathrm{~m}, 30 \mathrm{H}, \\
15 \mathrm{CH}_{2)}, \\
\delta 6.8-7.5(\mathrm{~m}, \\
4 \mathrm{H}, \mathrm{ArH}) \\
\delta 8.0,8.5 \text { and } 11.1 \\
(\mathrm{~s}, 3 \mathrm{H}, \mathrm{NH} \\
\text { exchangeable) }\end{array}$ & $\begin{array}{c}134(\mathrm{C} 1), 127(\mathrm{C} 2), \\
147(\mathrm{C} 3), 122(\mathrm{C} 4), \\
160.5(\mathrm{C} 5), \\
148(\mathrm{C} 6), \\
22-27 \text { (Long chain } \\
\text { C7) } \\
174.5(\mathrm{C} 8)\end{array}$ \\
\hline
\end{tabular}

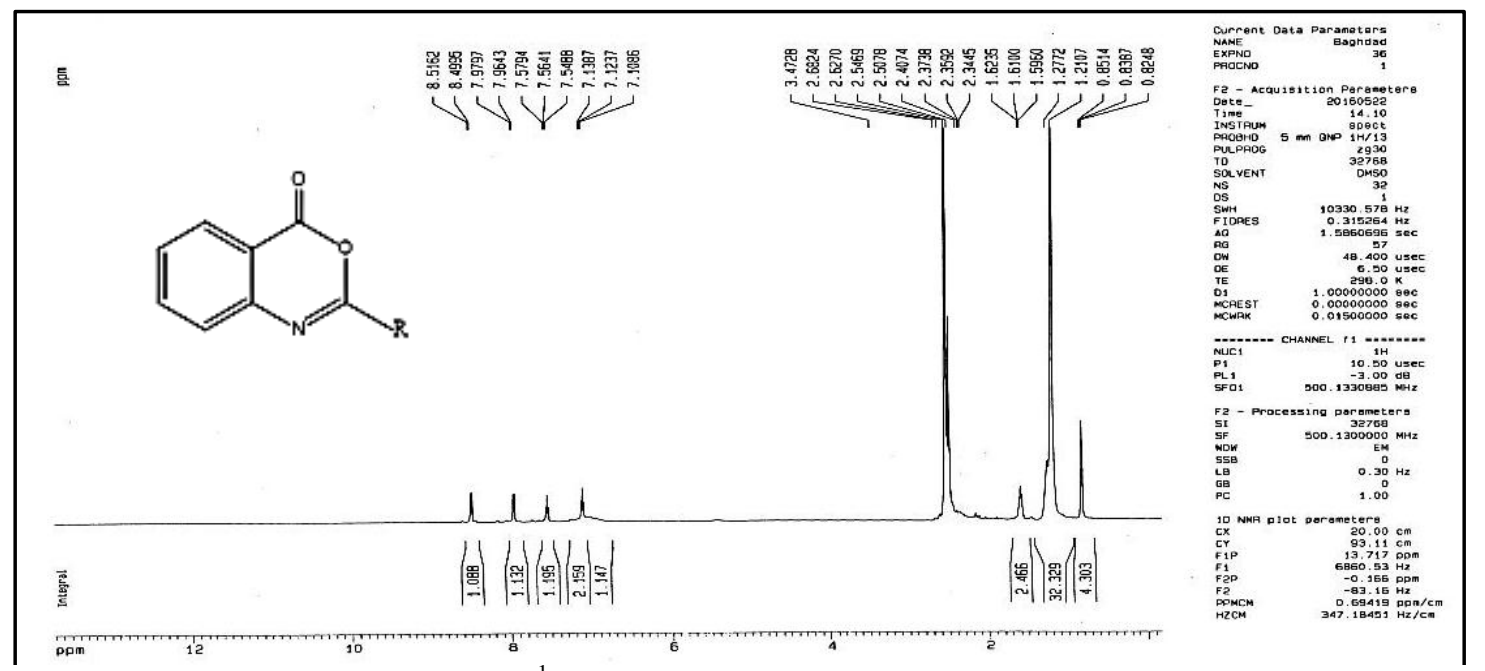

Fig (1) ${ }^{1} \mathrm{H}-\mathrm{NMR}$ spectrum of compound (1)

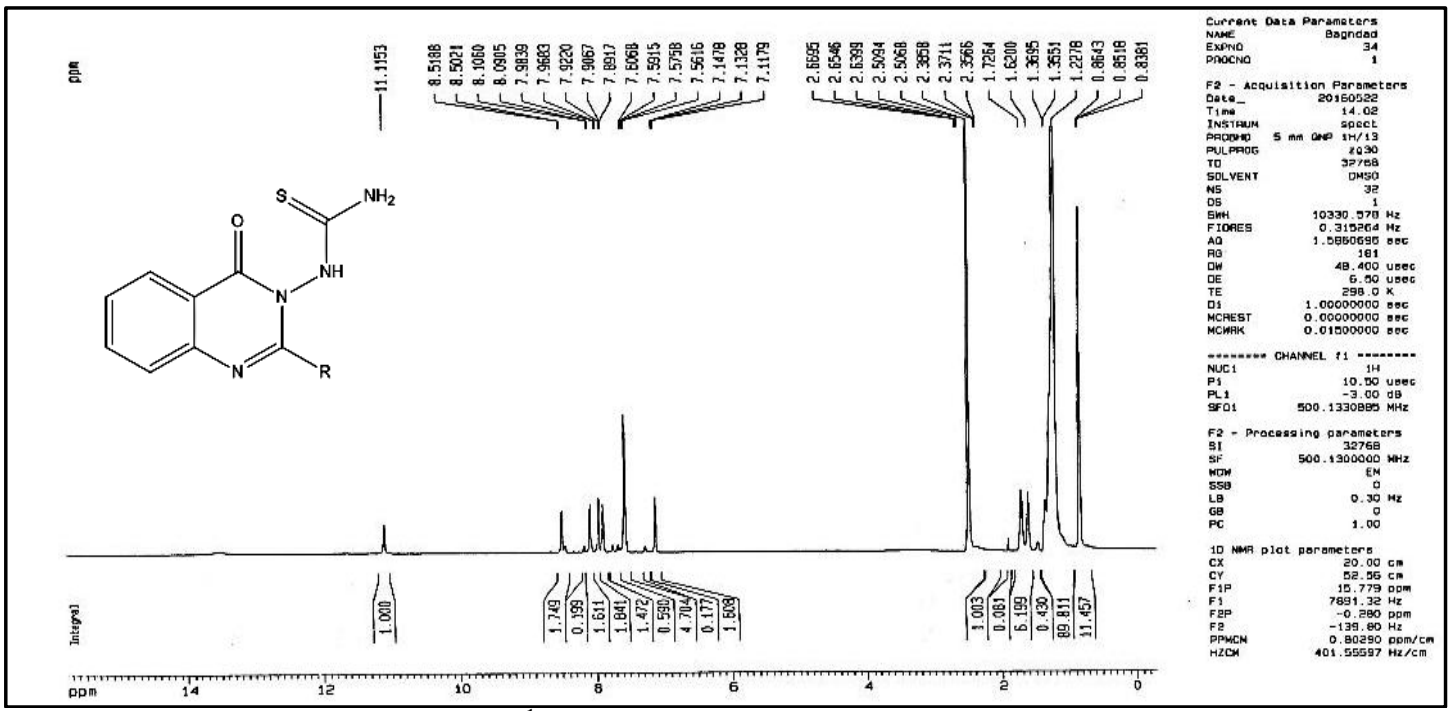

Fig (2) ${ }^{1} \mathrm{H}-\mathrm{NMR}$ spectrum of compound (2) 


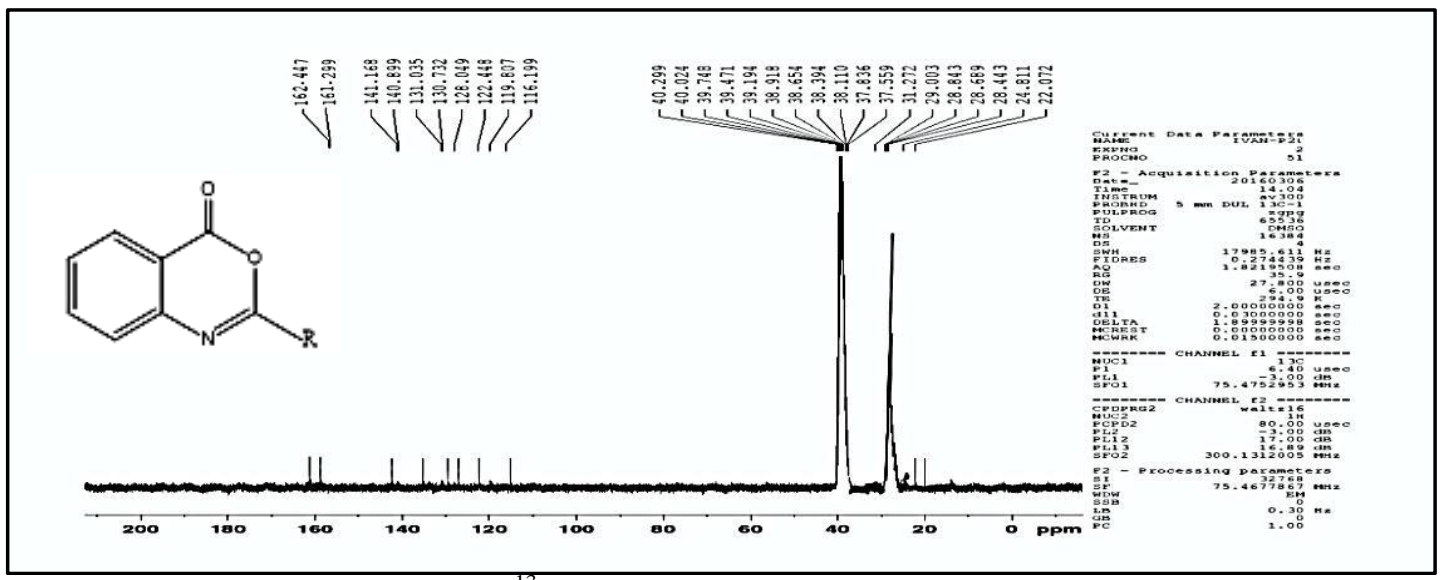

Fig (3) ${ }^{13}$ C-NMR spectrum of compound (1)

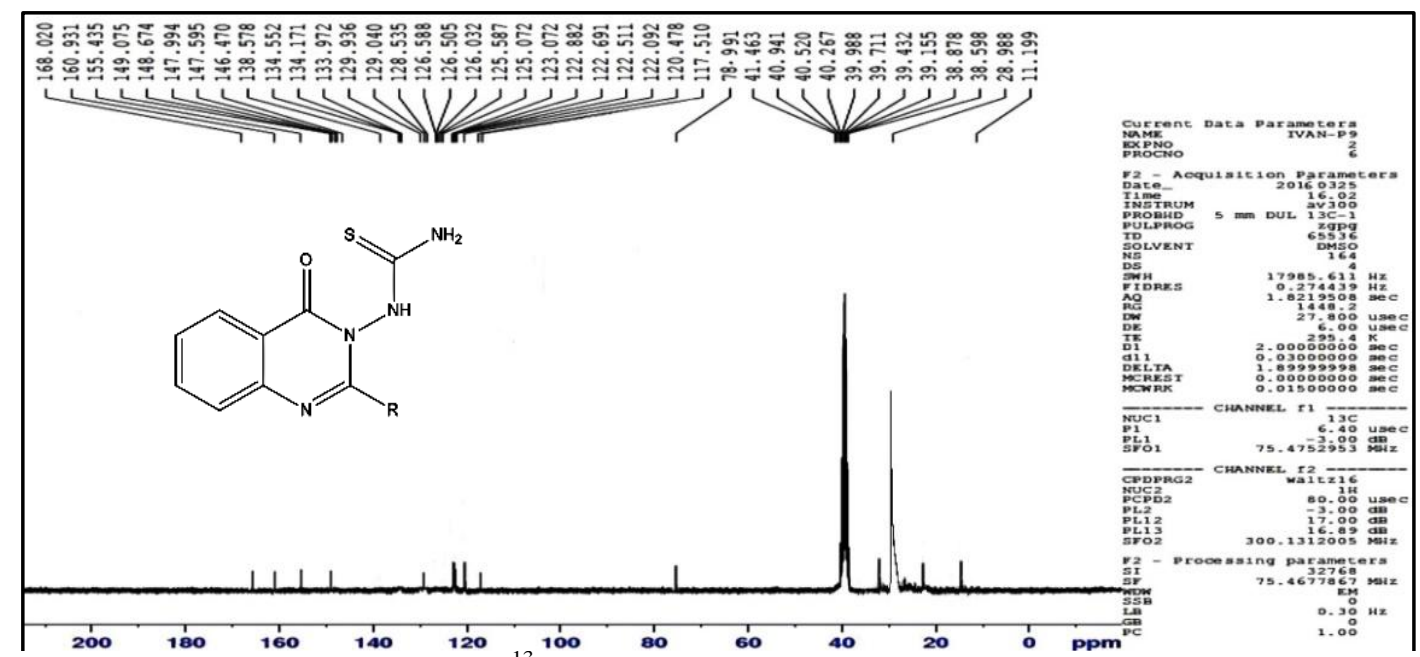

Fig (4) ${ }^{13} \mathrm{C}-\mathrm{NMR}$ spectrum of compound (2)

\subsection{Potentiodynamic polarization:}

The Tafel polarization behaviors of carbon steel in $2 \mathrm{NHCl}$ with the addition of various concentration of PQT at different temperature are shown in Fig (5). The corrosion kinetic parameters derived from these curves are presented in Table (2). From Table (2) it's clear that the corrosion current (Icorr), values of carbon steel decreases with the addition of PQT in $2 \mathrm{NHCl}$. The inhibition efficiency \% IE was calculated from the measured Icorr values using the equation (1):

$\% \mathrm{IE}=\frac{\text { Icorr (un) }-\operatorname{Icorr}(i)}{\text { Icorr (un })} * 100$

Where icorr (un) and icorr (i) are the uninhibited and inhibited corrosion current densities, respectively, which evaluated by extrapolated cathodic and anodic Tafel lines to corrosion potential.
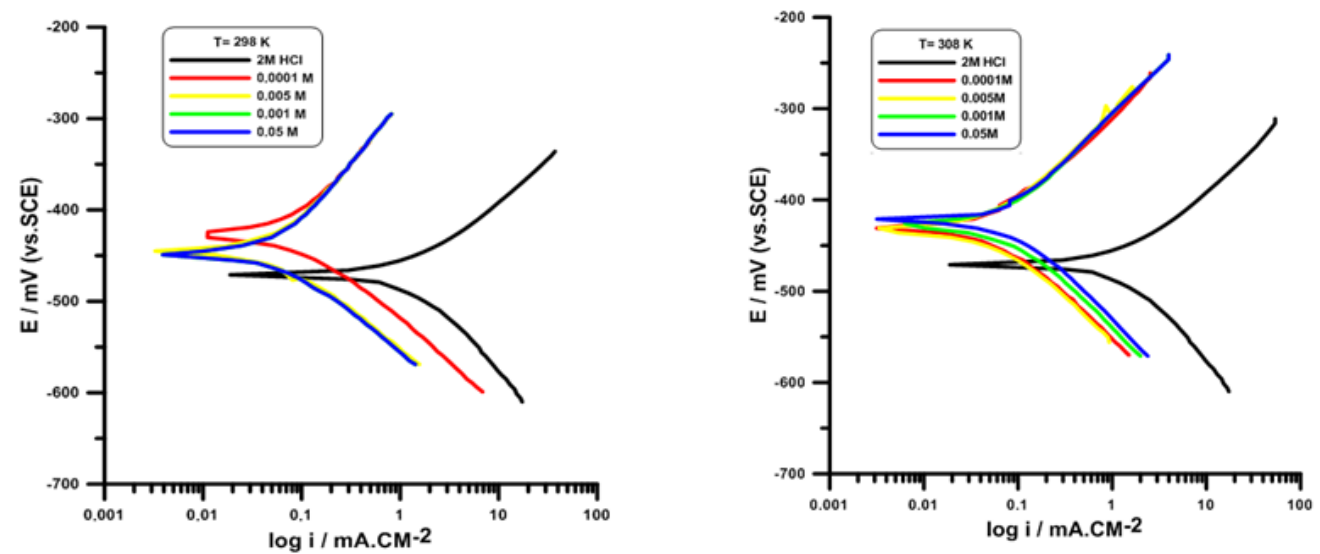

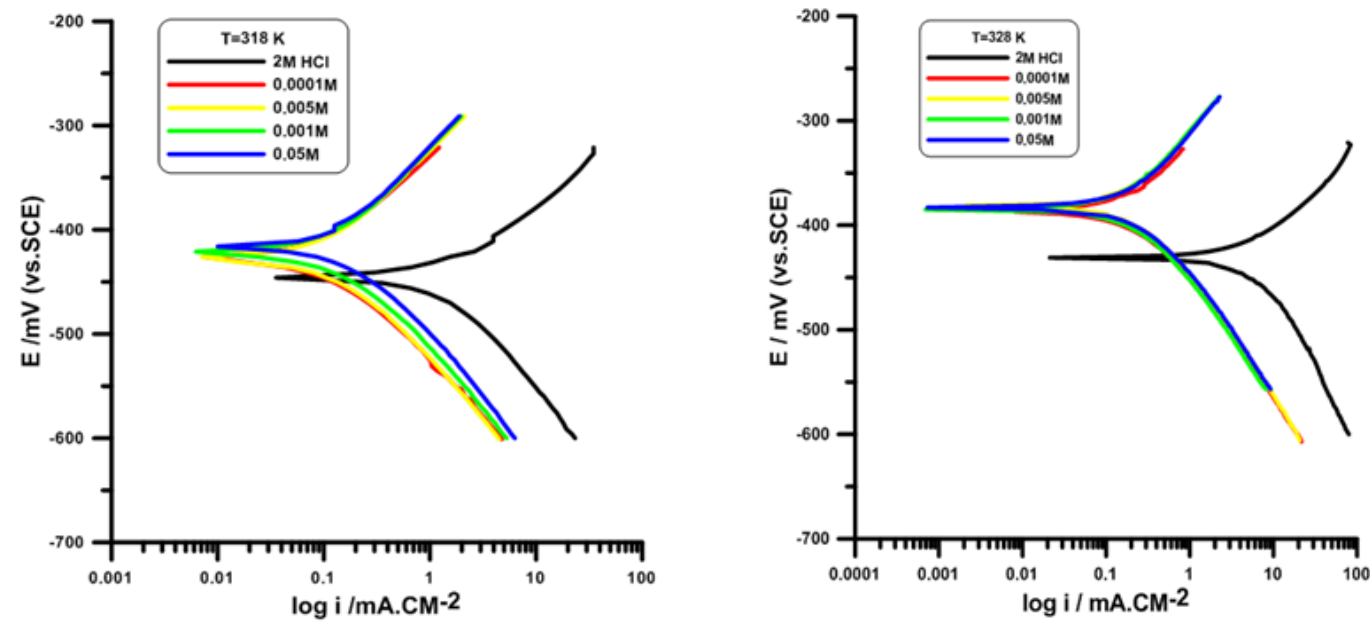

Fig (5) Typical Tafel plots of CS in $2 \mathrm{NHCl}$ in presence and absence of different concentration of (PQT) at 298, 308,318 and $328 \mathrm{~K}$.

Table (2) Corrosion parameters obtained for carbon steel in $2 \mathrm{~N} \mathrm{HCl}$ at different temperatures and

\begin{tabular}{|c|c|c|c|c|c|c|c|}
\hline Concentration(N) & $\mathbf{T} / \mathbf{K}$ & $\begin{array}{l}\text { Ecorr } \\
(\mathbf{m V})\end{array}$ & Icorr & $\begin{array}{c}\text { Bc } \\
\left(\mathbf{m V}, \text { dec-1) }^{1}\right)\end{array}$ & $\mathrm{Ba}\left(\mathrm{mV}_{1}\right)$.dec- & PE\% & $\square$ \\
\hline \multirow{4}{*}{ 2NHCl } & 298 & -458.6 & 959.34 & -84.6 & 69.7 & & \\
\hline & 308 & -472.2 & 803.55 & -78.5 & 68.5 & & \\
\hline & 318 & -447.7 & 853.12 & -81.8 & 62.9 & & \\
\hline & 328 & -430.2 & 3240 & $\begin{array}{l}-79.2 \\
\end{array}$ & 58.7 & & \\
\hline \multirow{4}{*}{0.0001} & 298 & -472.6 & 51.54 & $\begin{array}{l}-62.8 \\
\end{array}$ & 94.3 & 94.63 & 0.946 \\
\hline & 308 & -429 & 30.34 & -67.6 & 65.9 & 96.22 & 0.962 \\
\hline & 318 & -425.9 & 65.92 & -74.5 & 75.2 & 92.27 & 0.923 \\
\hline & 328 & -385.8 & 122.13 & -65.3 & 96.2 & 96.23 & 0.962 \\
\hline \multirow{4}{*}{0.005} & 298 & -445 & 39.68 & -68.8 & 59.8 & 95.87 & 0.959 \\
\hline & 308 & -426.7 & 35.57 & 85.6 & 72.3 & 95.57 & 0.956 \\
\hline & 318 & -426.7 & 71.64 & -73.9 & 80.9 & 91.60 & 0.916 \\
\hline & 328 & -379.7 & 127.81 & \begin{tabular}{|l|}
-69.1 \\
\end{tabular} & 68.9 & 96.06 & 0.961 \\
\hline \multirow{4}{*}{0.001} & 298 & -450.8 & 37.79 & -62.2 & 100 & 96.06 & 0.961 \\
\hline & 308 & -427 & 44.84 & -71.4 & 75.5 & 94.42 & 0.944 \\
\hline & 318 & -420.3 & 83.05 & $\begin{array}{l}-78.8 \\
\end{array}$ & 81.4 & 90.27 & 0.903 \\
\hline & 328 & -377.2 & 107.28 & -72.5 & 55.8 & 96.69 & 0.967 \\
\hline \multirow{4}{*}{0.05} & 298 & -449.2 & 39.02 & -65.5 & 101.7 & 95.93 & 0.959 \\
\hline & 308 & -421.5 & 53.48 & -74.2 & 80.2 & 93.34 & 0.933 \\
\hline & 318 & -414.6 & 94.29 & -74.1 & 84 & 88.95 & 0.889 \\
\hline & 328 & -379.6 & 135.3 & 72.4 & 69.7 & 95.82 & 0.958 \\
\hline
\end{tabular}

\subsection{Adsorption Isotherm Studies:}

The adsorption of isotherm study describes the adsorptive behavior of inhibitor in order to know the adsorption mechanism of inhibitor to the meatal surface. The most frequently used adsorption isotherms are Langmiur, Frumkin, Temkin and Freundlich isotherms. The Langmiur adsorption isotherm was found to provide the best description of the adsorptive behavior Fig (6). The Langmiur adsorption isotherm is given by the following equation: [16]

$$
\mathrm{C} / \Theta=1 / \mathrm{K}_{\mathrm{ads}}+\mathrm{C}
$$

Where $\mathrm{C}$ is concentration of inhibitor and Kads is adsorptive equilibrium constant representing the degree of adsorption (i.e., the higher value of Kads indicates that the inhibitor is strongly adsorbed on the metal surface); The Plot of $\mathrm{C} / \Theta$ Vs. $\mathrm{C}$ well yields a straight line,Fig(6) with regression coefficient, $\mathrm{R}^{2}$, almost equal to 1. This suggests that PQT in the present study obeyed the Langmuir isotherm, and there is a negligible interaction between the adsorbed molecules. The values of equilibrium constant Kads decreased with increasing temperature, which indicated that PQT is easily and forcefully adsorbed onto the C.S. surface at a lower temperature, weak and challenging at higher temperature

Free energy of adsorption was calculated using the following relations[17].

$\mathrm{K}_{\mathrm{ads}}=1 / 55.5 \operatorname{Exp}\left(-\Delta \mathrm{G}_{\mathrm{ads}} / \mathrm{RT}\right)$

$\Delta \mathrm{G}_{\mathrm{ads}}=-2.303 \mathrm{RT} \log \left(55.55 \mathrm{~K}_{\mathrm{ads}}\right)$

$\operatorname{Logk}_{\mathrm{ads}}=-\Delta \mathrm{H}_{\mathrm{ads}} / 2.303 \mathrm{RT}+\Delta \mathrm{S}_{\mathrm{ads}} / 2.303 \mathrm{R}+\log 1 / 55.55(5)$ 
The value 55.55 in the equation above is the concentration of water in solution inmol. $\mathrm{L}^{-1}$. The slope of variation of $\log (\mathrm{Kads})$ vs. $1 / \mathrm{T}=\left(-\Delta \mathrm{H}_{\mathrm{ads}} / 2.303 \mathrm{R}\right)$, so $\Delta \mathrm{H}_{\mathrm{ads}}=-2.59808$ Fig (7). A negative value of the $\Delta \mathrm{H}_{\mathrm{ads}}$ indicated that the adsorption process of inhibitor is an exothermic process; in an exothermic process physisorption is distinguished from chemisorption by considering that an exothermic value of a physisorption process is lower than- $40 \mathrm{~kJ}^{-\mathrm{mol}^{-1}}$ while the adsorption heat of chemisorption process approaches-100 kJ mol ${ }^{-}$ ${ }^{1}[18]$. In this study the standard adsorption heat is $\Delta \mathrm{H}^{\circ} \mathrm{ads}=-2.59808 \mathrm{~kJ} . \mathrm{mol}^{-1}$ postulates that physical adsorption is more favored. The negative value of standard adsorption entropy suggested that the adsorption was coupled with an increase of system order due to the adsorption of PQT on the C.S. surface. The data obtained from langmiur adsorption isotherm reported in Table (3). The negative values of $\Delta \mathrm{Gads}$ ensure the spontaneity of the adsorption process and stability of the adsorbed layer on the metal surface.

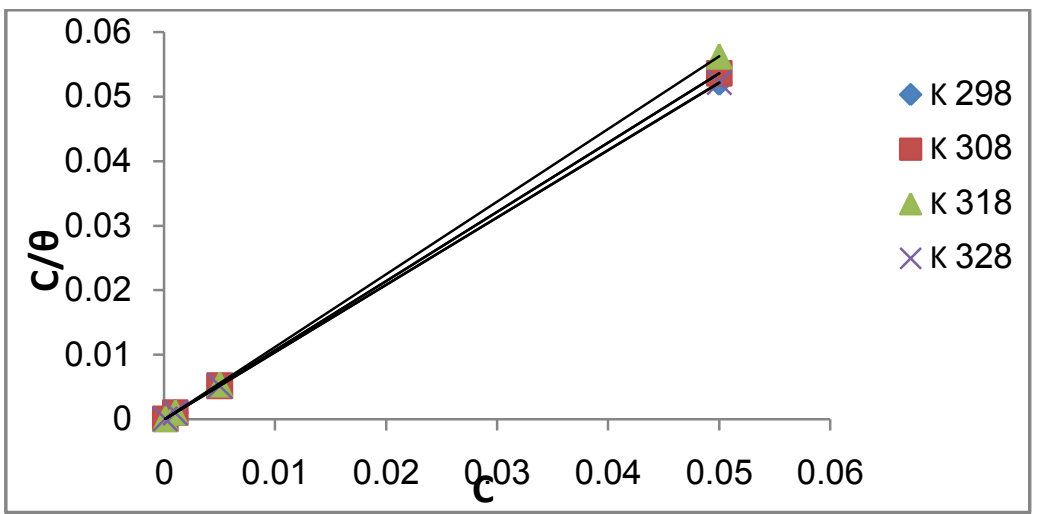

Fig (6) Langmuir adsorption isotherm of (PQT) on carbon steel in $2 \mathrm{~N} \mathrm{HCl}$ at different temperatures

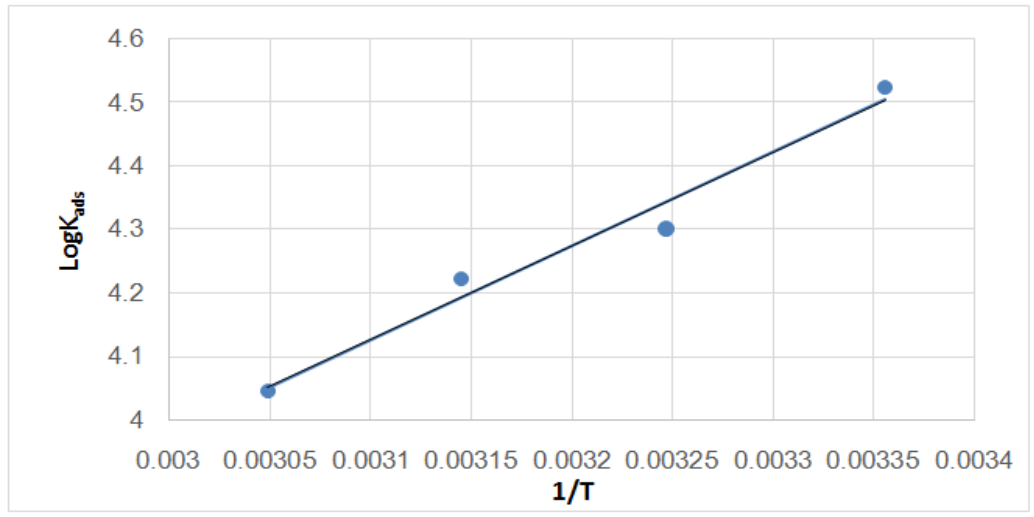

Fig (7) Plot of $\log$ Kads versus 1/T

Table (3) Thermodynamic parameters for adsorption of (PQT) on carbon steel surface in $2 \mathrm{~N} \mathrm{HCl}$ at different temperatures

\begin{tabular}{|c|c|c|c|c|c|}
\hline $\mathbf{T} / \mathbf{K}$ & $\mathbf{K}_{\text {ads }}$ & $\square$ G/kJ.mol ${ }^{1}$ & $\mathbf{R}^{2}$ & $\square \mathbf{H} / \mathbf{k J} . \mathbf{m o l}^{1}$ & $\square \mathrm{S} / \mathrm{J} . \mathrm{mol}^{1} . \mathrm{K}$ \\
\hline 298 & 33333.33 & -35.7618 & 0.9999 & \multirow{4}{*}{-2.59808} & \multirow{4}{*}{-0.02269} \\
\hline 308 & 20000.0 & -34.4959 & 1 & & \\
\hline 318 & 16666.67 & -34.0441 & 1 & & \\
\hline 328 & 11111.11 & -33.0394 & 0.9998 & & \\
\hline
\end{tabular}

\subsection{Corrosion Kinetic and Thermodynamic Study:}

To study the effect of temperature on the inhibition efficiencies of PQT, potentiostat polarization measurements were carried out in the temperature range $298-328 \mathrm{~K}$ in absence and presence of different PQT concentration.

The equation used to calculate the activation parameters of the corrosion process is Arrhenius Eq. (6). Moreover, transition state Eq. (7) was used. [19]

$\log ($ Icorr $)=\log \mathrm{A}-\mathrm{Ea} / 2.303 \mathrm{RT}$

$\log (\operatorname{Icorr} / \mathrm{T})=\log (\mathrm{K} / \mathrm{h})+\Delta \mathrm{S} * / 2.303 \mathrm{R}-\Delta \mathrm{H}^{*} / 2.303 \mathrm{RT}$

Where Icorr is corrosion current density, Ea is the apparent activation energy, $\mathrm{R}$ is the universal gas constant $\left(8.314 \mathrm{~J} \mathrm{~mol}^{-1} \mathrm{~K}^{-1}\right)$, $\mathrm{T}$ is temperature inK, A is the Arrhenius pre-exponential factor, $\mathrm{h}$ is the Plank's constant $\left(6.626 \times 10^{-34} \mathrm{~J} . \mathrm{s}\right), \mathrm{N}$ is the Avogadro's number $\left(6.022 \times 1023 \mathrm{~mol}^{-1}\right), \mathrm{K}$ is the Boltzmann constant, 
$\Delta \mathrm{H}^{*}$ is the enthalpy of activation and $\Delta \mathrm{S}^{*}$ is the entropy of activation. The plot of $\log$ Icorr against $1 / \mathrm{T}$ presented a linear relation with a slope (-Ea / $2.303 \mathrm{R})$ and the intercept of the extrapolated $\operatorname{line} \log \mathrm{A}$.

The result is listed in table (4) and Straight lines were obtained from the plots of log Icorr/T vs. 1/T, which are shown in Fig. (8). with the slope of $\left(-\Delta \mathrm{H}^{*} / 2.303 \mathrm{R}\right)$ and an intercept of $\left[\left(\log (\mathrm{R} / \mathrm{Nh})+\left(\Delta \mathrm{S}^{*} / 2.303 \mathrm{R}\right)\right]\right.$ from which the values of $\Delta \mathrm{H}^{*}$ and $\Delta \mathrm{S}^{*}$, respectively were calculated. From the corrosion current densities obtained from polarization curves at different temperatures in the absence and the presence of PQT as corrosion inhibitor, Arrhenius plots are shown in Figure (9) for a temperature range of (298-328 K) in $2 \mathrm{~N}$ acid concentration.[20]

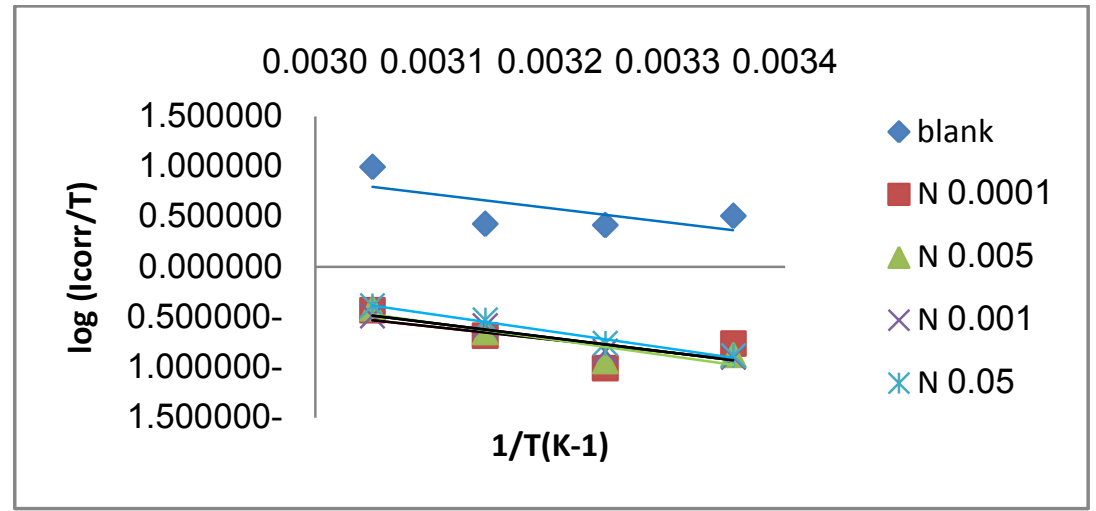

Fig (8) Transition state plot of carbon steel in $2 \mathrm{~N} \mathrm{HCl}$ contains different concentrations of (PQT) at different temperatures

$\Delta \mathrm{H}^{*}$ value for the corrosion of C.S in $2 \mathrm{~N} \mathrm{HCl}$ solution was $26.768 \mathrm{~kJ}^{\mathrm{m}} \mathrm{mol}^{-1}$ in absence of PQT, while in the presence of PQT inhibitor $\Delta \mathrm{H}^{*}$ values range are $(+24.125$ to +32.286$) \mathrm{kJ} \cdot \mathrm{mol}^{-1}$, the highest $\Delta \mathrm{H}^{*}$ value occurred with $0.05 \mathrm{~N}$ of PQT. However, the negative values of $\Delta$ Sact pointed to a greater order produced during the process of activation[21]. This can be achieved by the formation of activated complex and represents association or fixation with consequent loss in the degrees of freedom of the system during the process. The highest value of activation energy is $(58.7567) \mathrm{kJ}_{\mathrm{mol}} \mathrm{m}^{-1}$ was obtained with $0.005 \mathrm{~N}$.

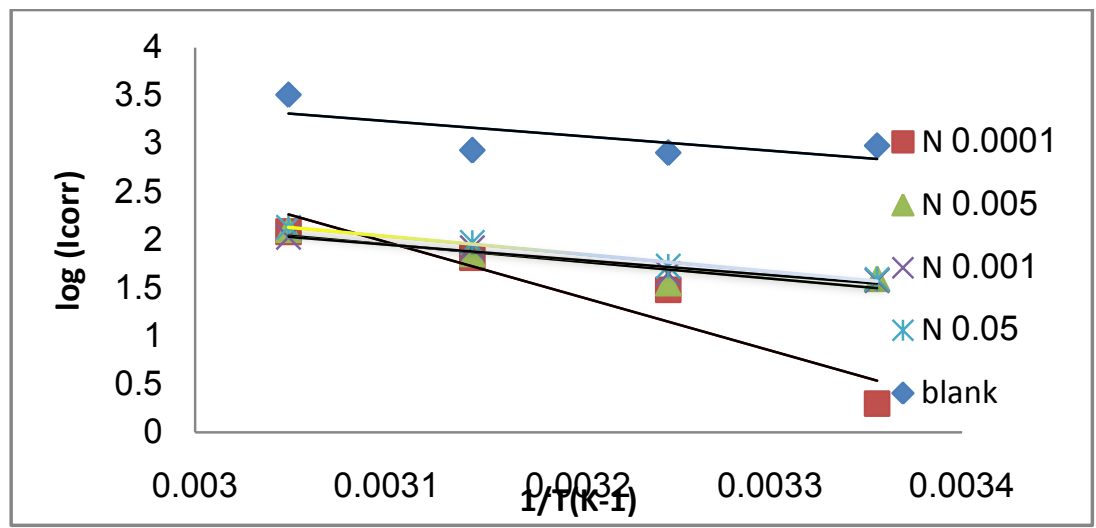

Fig (9) Arrhenius plot of carbon steel in $2 \mathrm{~N} \mathrm{HCl}$ contains different concentrations of (PQT) at different temperatures

Table (4) Corrosion kinetic parameters for carbon steel in $2 \mathrm{NHCl}$ in the absence and presence different concentration of (PQT)

\begin{tabular}{|c|c|c|c|c|c|c|c|c|}
\hline \multirow[b]{2}{*}{$\mathrm{C}_{\mathrm{PQT} / \mathrm{N}}$} & \multicolumn{4}{|c|}{$\square \mathbf{G} / \mathbf{k J} . \mathrm{mol}^{1}$} & \multirow{2}{*}{$\begin{array}{r}\square \mathbf{H}^{* /} \\
\text { k.J.mol} \\
\mathbf{1}\end{array}$} & \multirow{2}{*}{$\begin{array}{c}-\square \mathbf{S}^{* /} \\
\mathbf{k J} . \mathrm{mol}^{-1} \\
. \mathbf{K}^{-1}\end{array}$} & \multirow[b]{2}{*}{$\mathrm{Ea} / \mathrm{kJ} . \mathrm{mol}^{-1}$} & \multirow{2}{*}{$\begin{array}{c}\text { A } \\
\text { Molecules.cm } \\
\text {.S }^{-1}\end{array}$} \\
\hline & 298 & 308 & 318 & 328 & & & & \\
\hline $2 \mathrm{NHCl}$ & 56.775 & 57.782 & 58.789 & 59.796 & 26.768 & 0.1007 & 29.3660 & $5.86 * 10^{32}$ \\
\hline 0.0001 & 64.109 & 65.450 & 66.792 & 68.134 & 24.125 & 0.1342 & 53.9944 & $1.55 * 10^{31}$ \\
\hline 0.005 & 64.425 & 65.539 & 66.652 & 67.766 & 31.231 & 0.1114 & 58.7567 & $1.62 * 10^{30}$ \\
\hline 0.001 & 64.167 & 65.388 & 66.609 & 67.830 & 27.786 & 0.1221 & 52.7739 & $4.48 * 10^{29}$ \\
\hline 0.05 & 85.586 & 87.375 & 89.163 & 90.952 & 32.286 & 0.1789 & 34.8803 & $2.91 * 10^{29}$ \\
\hline
\end{tabular}




\subsection{Scanning Electron Microscopy (SEM):}

The SEM micrograph of the corroded carbon steel in $2 \mathrm{NHCl}$ in the prescienceand absence of PQT are shown in Fig (10 A-B). In figure A (absence of inhibitor) of bare carbon steel surface, notches and defects were observed, while a layer of closely packed film was obtained in figure $b$, and the surface was free from pits and it was smooth. It was concluded from figure $a-b$ that corrosion does not occur in prescience of PQT and hence corrosion was inhibited strongly when the inhibitor was present in the solution, then scanning electron microscopy observation, confirmed the existence of adsorbed protective film on the carbon steel surface.
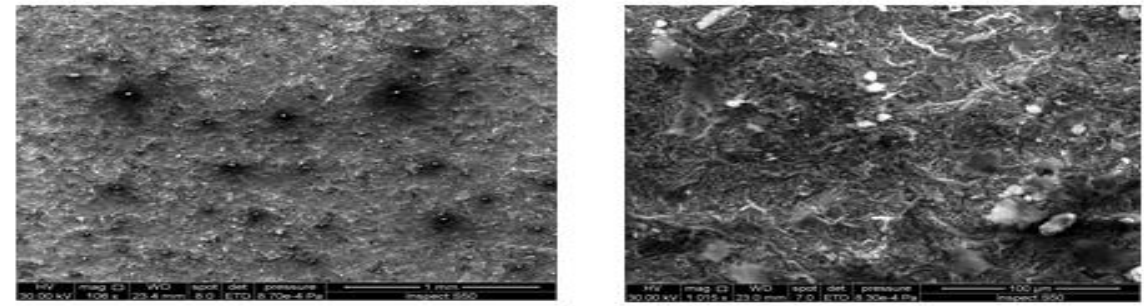

Figure A
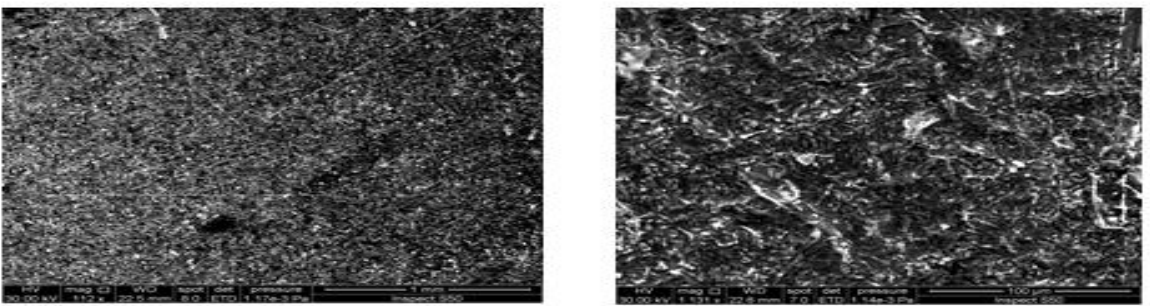

Figure B

Fig (10) surface characterization by SEM for carbon steel in $2 \mathrm{NHCl}$

(A) in the absence of inhibitor PQT

(B) in the presence of inhibitor PQT

\section{Conclusion}

From the overall experimental results the following conclusions can be deduced:

1- The result obtained from all electrochemical measurement showed that the inhibition efficiency is good at all the concentrations of inhibitor.

2- The inhibition efficiency obtained by the PQT is very good at all the temperature but it decreased at $328 \mathrm{k}$.

3- The adsorption of PQT on C-steel surface in $2 \mathrm{NHCl}$ solution follows Langmiur isotherm.

4- The Maximum inhibition efficiency is about 96.69 at $328 \mathrm{k}$ and $0.01 \mathrm{~N}$ concentration of PQT.

5- The inhibitive mechanism was proposed when $\mathrm{PQT}$ introduced into $2 \mathrm{NHCl}$ solution a thin film formed on the C-steel surface which cause decrease of the C-steel roughness and effectively protect C-steel from corrosion.

[1]. G.Trabanelli, Corrosion, 47,1991,410.

\section{References}

[2]. V.S. Sastri and J.R. Perumareddi, Corrosion, 53, 1997, 617

[3]. E.Elayyachy, A. El Idrissi, B. Hammouti, Corrossion. Sci. 48, 2006, 2470.

[4]. E.M. Sherif, A.A. Almajid, A.K. Bairamov and E. Al-Zahrani, Int. J, Electrochem.Sci. 6, 2011, 5372.

[5]. K.M. Ismail, Electrochim. Acta, 52, 2007, 7811.

[6]. D.D.N. Singh, T.B. Singh and B. Gaur, Corros Sci. 37, 1995,1005.

[7]. M.M.Ali, Y.A. Basyouni andS.Y.Abbas. Novel 4(3H) Quinazolinone containing biologically active, Thiazole, Pyrazole, 1,3,Dithiazole ,Pgridine, Chromene ,Pyrazolo pyrimidine and Pyranochromene of expected biological activity, World journal of chemistry 4(2), 2009, 161-170

[8]. M. M. Popa, F. Georgenscu, C. Draghici, E. Georgescu. And F.Dumitrascu. New 4(3H)-Quinazolinonium salts with potential biological activity. U.P.B.Sci.Bull.Series B.Vol.73, 2011, 3.

[9]. S.E.Fadi,M.Nashwa,A.Eman, and G.Gihan. New quinazolinone pyrimidine hybrid: synthesis, anti-inflammatory, and ulcerogenicity studies, E.JM.Ch.,53, 2012, 141-149

[10]. Y.Convindaraj, V.S.Karthikeyan, V.Melanaphura, , G.Setal.Synthesis and In-vivo Anticancer Screening of [(Bis-2- chloro ethyl) Amino] Amino] Methyl]-6-8-Dinito-1- (4-substitued Ethyl) - H- quinazoline-4-one derivative. AcademicaJornal of Cancer Research 2, 2009,73-77.

[11]. A.A. Elsawy, S.K.Mohanad, Synthesis, reaction and biological evaluation of pentadecanylbenzoxazinone and pentadecanylquinazolinone derivatives, journal of chemical and pharmaceutical research , 4(5), 2012, 2755 - 2762.

[12]. M.S.Amine, A.A.Aly, R.Elsayed, Synthesis and surface active properties of condensed and non-condensed quinazolinone derivatives of industrial application, 45B, 2006, 1020-1027.

[13]. N.Koj, Infrared absorption spectroscopy, 1st ed., NankodoCompanylimited, Tokyo, 1962. 
[14]. R.Shriner, R.Fusion and T.Morril, .The systematic identification of organic compounds, 8thed, Jhon Wiley and Sons, New York 1980 .

[15]. C.Hui, F.Zhenghao,S.Jinling,S.Wenyan, “Corrosion inhibitor of mild steel by aloes extract in HCl solution”. International Journal of Electrochemical Science, 8, 2013, 720,734.

[16]. S. S. Al-Luaibi, A.Seta, H. Abdel-Amir, "Thermodynamic properties of amino melamine Formaldehyde as corrosion inhibitor for steel in sulfuric acid solution", J. Mater. Environ. Sci. 2(2), 2011, 148-155.

[17]. m. Pourbaix, "Applications of electrochemistry in corrosion science and in practice" Corrosion Science, vol. 14, 1974, 25-82.

[18]. S.A. Umoren, I.B. Obot, E.E. Ebenso, "Corrosion inhibition of aluminum using exudate gum from Pachylobus edulis in the presence of halide ions in HCl", E-journal Chem., 5 ,2008, 355-364.

[19]. S.Bilgic, andN.Caliskan, "The effect of N-(1-toluidine) salicylaldimine on the corrosion of austenitic chromium-nickel steel", Appl. Surf. Sci. 152(1-2), 1999, 107-114.

[20]. E. A. Noor, "Evaluation of inhibitive action of some quaternary $\mathrm{N}$ heterocyclic compounds on the corrosion of $\mathrm{Al}-\mathrm{Cu}$ alloy in hydrochloric acid", Mater. Chem. Phys. 114, 2009, 533-541. 